4. Kalashnikova, S. (Eds.) (2017). Rozvytok instytutsiinoho potentsialu universytetiv u konteksti hlobalnoho liderstva: kolektyvna monohrafia [Developing the institutional capacity of universities in the context of global leadership] Kyiv: Instytut vyshchoi osvity NAPN Ukrainy [in Ukrainian].

5. Kremen, V. H. (Eds.) (2017). Rozvytok suchasnoi osvity: osvitolohichni naholosy. Naukovi pratsi [Development of modern education: educational emphasis] Kyiv: Kyivskyi universytet imeni Borysa Hrinchenka [in Ukrainian].

6. Rozshyrenyi hlosarii terminiv ta poniat st. 42 «Akademichna dobrochesnist» Zakonu Ukrainy «Pro osvitu» (vid 5 veresnia 2017 r.) [Extended Glossary of Terms and Concepts Art. 42 «Academic Integrity» of the Law of Ukraine «On Education»] (n.d.) mon.gov.ua. Retrieved from https://mon.gov.ua/storage/app/media/vishcha-osvita/2018/10/25/glyusariy.pdf [in Ukrainian].

7. Tsokur, O. S. (2009). «Kodeks chesti» v systemi vyshchoi osvity SShA [«Honor Code» in the US higher education system]. Visnyk Cherkaskoho natsionalnoho universytetu imeni Bohdana Khmelnytskoho - Bulletin of Cherkasy National University named after Bohdan Khmelnytsky, 150. 57-62 [in Ukrainian].

8. Shlikhta, N., Shlikhta, I. (2016) Osnovy akademichnoho pysma : Metodychni rekomendatsii ta prohrama kursu [Basics of Academic Writing: Guidelines and Course Program]. Kyiv [in Ukrainian].

9. Aultman, L. P., Williams-Johnson, M. R. \& Schutz, P. A. (2009) Boundary dilemmas in teacher-student relationships: Struggling with «the line». Teaching and Teacher Education: An International Journal of Research and Studies. 25(5), p. 636-646. Retrieved from https://www.learntechlib.org/p/195556/.

10. McCabe, D.L., Trevino, L. K. (1996). «What We Know About Cheating in College: Longitudinal Trends and Recent Developments». Change. Vol. 28, No. 1, 28-33.

11. Stanford University. Retrieved from http:// www.stanford.edu

12. UC Berkeley. Retrieved from http://www. berkeley.edu.

13. University of Cambridge. Retrieved from http://www.cam.ac.uk.

\title{
Slobodianiuk 0 . M. State of the study of ensuring academic integrity in higher education in Ukraine
}

The article analyzes the state of research on the problem of ensuring academic integrity in higher education in Ukraine. In developed countries, academic integrity is defined as critically important to ensure credibility for scientific outcomes and to confirm the educational outcomes of higher education graduates. That is why the development of common policies and procedures for ensuring academic integrity at the national and institutional levels is a prerequisite for deepening European integration and for its functional expansion in the field of education. The purpose of the article is to identify positive developments in the way of overcoming academic malpractice. The article substantiates the importance for the formation of academic virtue in the educational environment for the adoption of a number of regulatory documents, namely the Law of Ukraine «On Higher Education» (2014), the Law of Ukraine «On Education» (2017), the Law of Ukraine "On Scientific and scientific and technical activities» (2016) and other documents. The experience of maintaining high educational standards at the institutional level through the development, discussion and implementation of documents in the Universities of Ukraine: "Regulations on Academic Integrity», "Code of Academic Integrity» and "Declarations of research staff and student» are analyzed. It is emphasized that in Ukrainian practice there is a considerable risk of formal imitation «implementation» of the recommendations of international organizations, with simple rewriting of translated procedures and policies, without detailed discussion or even familiarization of all participants of the academic process with these documents. A sign of the systematic evaluation of progress in the process of academic integrity formation is the process of further amendments to the strategic documents and legal acts regulating the observance of the standards of academic integrity and the procedure for their violation.

Key words: higher education of Ukraine, academic integrity, ensuring academic integrity, manifestations of academic integrity, plagiarism.

\author{
УДК 378:364-43 \\ DOI https://doi.org/10.31392/2311-5491/2019-70.57
}

Співак Я. $\boldsymbol{O}$.

\section{ХАРАКТЕРИСТИКА ПРОФЕСІЙНИХ ЯКОСТЕЙ СУЧАСНОГО ФАХІВЦЯ ІЗ СОЦІАЛЬНОЇ РОБОТИ ЗАХИСТУ ПРАВ МОЛОДІ}

Статтю присвячено характеристиці основних професійних якостей сучасного фахівия із соціальної роботи захисту прав молоді. Представлено перелік професійних знань, умінь та навичок, якими має володіти сучасний фахівець із сочіальної роботи захисту прав молоді. У ході дослідження окреслено специфіку професійної діяльності фахівців із захисту прав молоді. Виділено професійно важливі психологічні (психічні, інтелектуальні, професійна самосвідомість), морально-етичні, вольові та професійно-операційні (професійні знання, організаторсько-комунікативні здібності) якості сучасного фахівия із сочіальної роботи. Визначено складові компоненти професіоналізму сучасного фахівия із сочіальної роботи, щчо включає в себе здатність аналізувати ситуацію, правильно ї̈ сприймати, брати до уваги всі існуючі альтернативи та робити необхідний вибір; вміння встановлювати контакт із людьми, здійснювати диферениійований підхід до клієнтів; здібність управляти діяльністю соџіальної служби, використовувати в соиіальної роботі технологї̈ проектування, моделювання. Наголошено на важливості комунікативної складової частини, в основі якої покладена комунікативна техніка спілкування, володіння якою є важливою ознакою професійної придатності фахівия із соиіальної роботи. Охарактеризовано особистість фахівия із соиіальної роботи щодо захисту прав 
молоді, висвітлено комплекс його професійних обов'язків. Зосереджено увагу на ролі сучасного фахівия із соиіального захисту прав молоді, щзо виступає в ролі посередника, організатора, адміністратора, коли його діяльність спрямована на допомогу в подоланні проблем особи, щяо знаходиться у важкій життєвій ситуації. Визначено основні функції роботи соціального працівника щзодо сощіального захисту прав молоді. Сучасний аналіз навчального процесу та численних досліджень показав, щчо мета діяльності сучасного фахівия із соиіальної роботи захисту прав молоді полягає в допомозі людям пристосуватися до складного, спеціалізованого, технологічно орієнтованого суспільства. У результаті дослідження було висвітлено сучасні виклики суспільства щуодо змісту професійної підготовки фахівия із соціального захисту прав молоді. Висвітлено мету практичної діяльності фахівиів із соиіального захисту прав молодi.

Ключові слова: сочіальний захист, сочіальний захист прав молоді, професійні якості, фахівці сочіальної сфери.

На сучасному етапі розвитку суспільства питання підготовки компетентних фахівців соціальної сфери, які можуть надавати кваліфіковану допомогу у вирішенні різноманітних проблем, зокрема забезпечення прав та рівних можливостей молоді, поступово зростає. Специфіка сучасної соціальної роботи вимагає високого рівня професіоналізму соціального працівника, для якого характерні індивідуальна своєрідність й унікальність умов протікання.

Різноманітні аспекти формування професійних якостей майбутніх соціальних працівників із соціальної роботи захисту прав молоді розглядають І. Бех, М. Гончарова-Горянська, М. Докторович, А. Капська, Л. Рябовол, О. Ткачук та ін. (загальнотеоретичні й концептуально-методологічні засади соціально-правової компетентності); деякі аспекти становлення соціального працівника як професіонала розкриті в наукових дослідженнях В. Бочарової, Н. Клименко, А. Ляшенко, В. Плащова, В. Поліщук, В. Сластьоніна, Н. Шмельової та ін.; обгрунтовані концепції соціальної роботи в різних сферах життєдіяльності індивіда (С. Архипова, 3. Борисенко, Н. Гайдук, І. Козубовська, В. Синьов та ін.).

Головною метою статті $\epsilon$ характеристика професійних якостей сучасного фахівця із соціальної роботи захисту прав молоді.

Зміни, що відбуваються в нашій країні, викликали необхідність формування та розвитку професійних якостей сучасного фахівця із соціальної роботи захисту прав молоді. Основна функція соціального працівника полягає в допомозі людям пристосуватися до складного, спеціалізованого, технологічно орієнтованого суспільства, частиною якого $є$ найближче оточення - сім'я, трудовий колектив, сусіди, однолітки тощо, 3 метою поліпшення якості життя та функціонування соціуму.

Концепція соціальної роботи і професія соціального працівника є новаторськими для України, тому підготовка фахівців цього профілю в закладах вищої освіти потребує інноваційного підходу до організації навчання студентів на основі модернізації технологічно-процесуального і змістового наповнення та структурного моделювання оптимальної системи професійної підготовки майбутніх соціальних працівників шляхом упровадження інноваційних освітніх систем і педагогічних технологій.

Професійні обов'язки сучасного фахівця із соціальної роботи зумовлюють його ролі. Він виступає як соціальний педагог, учитель, вихователь, експерт, консультант, коли надає поради, навчає різним умінням, ефективним методам родинного планування і господарювання, встановлює зворотній зв'язок, застосовує рольові ігри та інше. Сучасний фахівець виступає в ролі посередника, організатора, адміністратора, коли його діяльність спрямована на допомогу в подоланні проблем особи, що знаходиться у важкій життєвій ситуації. Він виступає в ролі соціального адвоката, коли представляє інтереси клієнта або групи клієнтів, наприклад, під час встановлення або позбавлення батьківських прав, опікунства тощо.

Теорія і практика соціальної роботи доводить, що стиль поведінки, розвиток професійних якостей сучасного фахівця із соціальної роботи зумовлені сукупністю його професійних знань, умінь, навичок; комплексом психологічних особливостей та професійно важливих якостей та здібностей. Здатність досягати найвищих успіхів у професійній діяльності багато в чому залежить від самооціночних здібностей (самоконтроль, самовдосконалення, самоосвіта). Фахівець повинен бути психологічно готовим до діяльності в соціальній сфері, мати сформоване професійне мислення, вміти самостійно аналізувати конкретну ситуацію, оцінювати можливі наслідки та брати відповідальність за обрані рішення, які часто пов'язані з життям людини.

Виділимо професійно важливі психологічні якості сучасного фахівця із соціальної роботи:

- психічні: особливості психічних процесів (пам'яті, мислення, сприймання, відчуття, уяви); увага, як стан свідомості та умова виконання діяльності; психічні стани (працездатність, енергійність, ініціативність, стресостійкість, низький рівень тривожності); емоційно-вольові прояви (стриманість, наполегливість, послідовність, імпульсивність та ін.);

- інтелектуальні: соціальний інтелект (здатність аналізувати стани інших людей, передбачати розвиток подій); творче мислення (здатність приймати нестандартні рішення, діяти в невизначених ситуаціях); аналітичність, реалістичність, інтуїтивність, прогностичність, критичність, гнучкість мислення; ерудиція та кругозір; достатній освітній рівень та ін.; 
- професійна самосвідомість: самоконтроль, самокритичність, адекватна самооцінка, прагнення до самовдосконалення й самоосвіти, самонавіюваність, уміння керувати власними емоціями та поведінкою, змінювати власні стани [2, с. 84].

Обов'язковими в успішній професійній діяльності є професійно важливі морально-етичні та вольові якості:

1) емпатійність (здатність до співчуття, співпереживання, відчуття настрою людини, розуміння їі внутрішнього світу);

2) делікатність, тактовність, уважність до клієнта (звернення уваги на настрій клієнта, його самопочуття, дотримання принципу «не зашкодь»);

3) терпимість (повага до інтересів, переконань, ідеалів, потреб, звичок інших людей, сприймання людини такою, якою вона є, з їі правом на обраний спосіб життя);

4) витримка і терплячість (контроль над власними емоціями на виклики роздратованості, агресивності та ін.);

5) висока духовна культура й моральність, етична поведінка, гуманність, милосердя, чуйність, безкорисливість (спрямованість на інтереси, потреби і захист людської гідності клієнта, бажання допомогти, симпатія до інших);

6) чесність (правдивість у поясненні становища клієнта, можливостей вирішення його проблем, можливих труднощів);

7) об’єктивність та справедливість (рівне ставлення до клієнта, незважаючи на власні симпатії, адекватне оцінювання його проблем);

8) моральна чистота у професійних справах, конфіденційність (уміння зберігати таємницю, якщо вона не несе загрозу іншим людям);

9) порядність, відповідальність (моральна відповідальність за свою поведінку і наслідки власних дій);

10)емоційно-позитивне ставлення до людей: доброзичливість, доброта, любов до людей, оптимізм (уміння сприймати людину як самоцінність, формувати позитивні почуття до неї, вселяти надію на краще) [1, с. 67].

Акцентуємо увагу на професійно-операційних якостях та здібностях:

- професійні знання: теоретичні (із психології, педагогіки, соціології, медицини, права, геронтології та ін.) та практичні (володіння технологіями соціальної роботи), вміння застосовувати теоретичні знання на практиці, навички роботи з різними категоріями клієнтів, що знаходяться в різних умовах і ситуаціях;

- організаторсько-комунікативні здібності: вміння швидко встановлювати контакт із людьми, виявляти їхні установки, очікування; атрактивність (привабливість особистості, вміння вислухати клієнта та спрямувати бесіду в конструктивне русло); вміння викликати симпатію і довіру співрозмовника й створювати сприятливу атмосферу у взаємовідносинах із ним; красномовство (вміння впливати і переконувати).

Професіоналізм фахівця із соціальної роботи включає [3]: здатність аналізувати ситуацію, правильно iii сприймати, брати до уваги всі існуючі альтернативи та робити необхідний вибір; уміння встановлювати контакт із людьми, здійснювати диференційований підхід до клієнтів; здібність управляти діяльністю соціальної служби, використовувати в соціальної роботі технології проектування, моделювання та інші.

Серед компонентів професіоналізму особливе значення має його комунікативна складова частина. Оскільки різноманіття форм взаємодії в соціальній роботі проявляє себе через численні форм соціальної комунікації, вона пронизує всі сторони професійної діяльності фахівця. Незаперечним є те, що соціальний працівник повинен уміти вислухати й зрозуміти, пояснити й довести, запитати й відповісти, переконати, створити атмосферу довіри в бесіді, знайти індивідуальний психологічний підхід до клієнта, розв'язати конфлікт, зняти напругу. В основі такої діяльності лежить комунікативна техніка спілкування, володіння якою є важливою ознакою професійної придатності фахівця із соціальної роботи.

Висновки. Таким чином, сучасний фахівець із соціальної роботи захисту прав молоді має бути гуманним, поважати молодь, яка потребує допомоги, підтримати їі професійно і морально, надихнути на подолання труднощів, вселити віру у власні сили й можливість повернення до гідного життя. Як соціолог і педагог він має глибоко знати правові, моральні, психологічні регулятори життєдіяльності людей, має бути здатним і готовим прийти їм на допомогу, надавати ії кваліфіковано, доброзичливо і терпеливо. Чим складнішим для опанування і соціально значущішим є фах, тим розвиненішими мають бути професійні якості фахівця із соціальної роботи захисту прав молоді.

Перспективи подальших наукових розвідок убачаються в розробленні освітньо-соціальної моделі формування професійної компетентності майбутніх соціальних працівників із соціальної роботи захисту прав молоді.

\section{Використана література:}

1. Докторович М.О. Професійна компетентність соціального педагога. Вісн. Глухівського ДПУ. 2010. Вип. 15. С. 64-69.

2. Капська А.Й., Волинська Л.В., Карпенко О.Г., Филипчук В.С. Комунікативна професійна компетентність як умова взаємодії соціального працівника з клієнтом / За ред. А.Й. Капської. Київ : ДЦСМ, 2003. 87 с. 
3. Поліщук В.А. Теорія і методика професійної підготовки соціальних педагогів в умовах неперервної освіти : дис. ... доктора пед. наук : 13.00.04. Тернопіль, 2006. 454 с.

\section{References:}

1. Doktorovych M. O. (2010). [Professional competence of social pedagogue]. Profesiina kompetentnist sotsialnoho pedahoha. Visn.Hlukhivskoho DPU. Vyp. 15, 64-69 pp.

2. Kapska A. Y., Volynska L. V., Karpenko O. H., Fylypchuk V. S. (2003). [Communicative professional competence as a condition of social worker interaction with the client]. Komunikatyvna profesiina kompetentnist yak umova vzaiemodii sotsialnoho pratsivnyka z kliientom. K.: DTsSM, 87 p.

3. Polishchuk V. A. (2006). [Theory and methodology of vocational training of social pedagogue in the conditions of continuous education]. Teoriia i metodyka profesiinoi pidhotovky sotsialnykh pedahohiv v umovakh neperervnoi osvity : dys. ... doktora ped. nauk : 13.00.04. Ternopil, $454 \mathrm{p}$.

Spivak Ya. O. Characteristics of professional qualities of a modern specialist in social work for youth rights protection

The article is devoted to characterization of basic professional qualities of a modern specialist in social work of youth rights protection. The list of professional knowledge and skills that a modern specialist in social work for youth rights protection should possess is presented. The study outlines the specific professional activities of youth protection professionals. Occupationally important psychological (psychic, intellectual, professional self-consciousness), moral-ethical, volitional and professional-operational (professional knowledge, organizational-communicative abilities) qualities of the modern social work specialist are distinguished. The components of professionalism of a modern social work specialist are defined, which includes the ability to analyze a situation, properly perceive it, take into account all existing alternatives and make the necessary choice; ability to make contact with people, to differentiate approach to clients; ability to manage social service activities, use in social work technology of design, modeling. The importance of the communicative component, which is based on the communicative communication technique, the possession of which is an important sign of the professional fitness of a social work specialist, is emphasized. The personality of the social work specialist for the protection of youth rights is described and the complex of his professional duties is highlighted. The focus is on the role of a modern youth social protection specialist who acts as a mediator, organizer, administrator when his activities are aimed at helping to overcome the problems of a person in difficult life situation personality The main functions of the social worker's work on social protection of youth rights are identified. Modern analysis of the educational process and numerous studies have shown that the purpose of the activity of a modern social work specialist for the protection of youth rights is to help people to adapt to a complex, specialized, technologically oriented society. The research highlighted the societal challenges of the content of the training of a specialist in social protection of youth rights. The purpose of practical activity of specialists in social protection of youth rights is highlighted.

Key words: social protection, social protection of youth rights, professional qualities, specialists in the social sphere. 